\title{
The Laetiporus sulphureus Fermented Product Enhances the Antioxidant Status, Intestinal Tight Junction, and Morphology of Broiler Chickens
}

\author{
Wei Chih Lin $^{1}$ and Tzu Tai Lee ${ }^{1,2, *(1)}$ \\ 1 Department of Animal Science, National Chung Hsing University, Taichung 402, Taiwan; \\ waynezi2227738@gmail.com \\ 2 The iEGG and Animal Biotechnology Center, National Chung Hsing University, Taichung 402, Taiwan \\ * Correspondence: ttlee@dragon.nchu.edu.tw; Tel.: +886-4-22840366; Fax: +886-4-22860265
}

Citation: Lin, W.C.; Lee, T.T. The Laetiporus sulphureus Fermented Product Enhances the Antioxidant Status, Intestinal Tight Junction, and Morphology of Broiler Chickens. Animals 2021, 11, 149.

https://doi.org/10.3390/ani11010149

Received: 5 December 2020

Accepted: 7 January 2021

Published: 11 January 2021

Publisher's Note: MDPI stays neutral with regard to jurisdictional clai$\mathrm{ms}$ in published maps and institutional affiliations.

Copyright: $(\odot 2021$ by the authors. Licensee MDPI, Basel, Switzerland. This article is an open access article distributed under the terms and conditions of the Creative Commons Attribution (CC BY) license (https:// creativecommons.org/licenses/by/ $4.0 /)$.
Simple Summary: This study investigated the effects of the Laetiporus sulphureus fermented product (FL) as a feed supplement on antioxidant activities, intestinal Tight Junction (TJ) mRNA expression, and the intestinal morphology of broiler chickens. FL supplementation could potentially enhance the feed conversion ratio in broilers by improving their antioxidative status, TJ mRNA expression, and intestinal morphology. Broilers supplemented with 5\% FL exhibited the best overall results on improving antioxidant status, TJ mRNA expression, and intestinal morphology.

Abstract: The Laetiporus sp. is a fungal species that is traditionally used for medicinal purposes. This study investigated the effects of the Laetiporus sulphureus fermented product (FL) as a feed supplementation on the antioxidant activities, the intestinal Tight Junction (TJ) mRNA expression, and the intestinal morphology of broiler chickens. Four-hundred one-day-old male broilers (Ross 308) were randomly allocated to five experimental diets: (1) a corn-soybean meal basal diet (control), (2) a basal diet replaced with 5\% Wheat Bran (5\% WB), (3) a basal diet replaced with 10\% WB (10\% WB), (4) a basal diet replaced with 5\% FL (5\% FL), and (5) a basal diet replaced with 10\% FL (10\% FL). The FL-supplemented groups exhibited a better feed conversion ratio in the overall experimental period compared to the WB and control groups. The serum antioxidant profiles of 35-day-old broilers showed that, compared to the control and 10\% WB groups, the 5\% FL supplementation group had a significantly increased superoxide dismutase activity, while it down-regulated the concentration of malondialdehyde in the serum $(p<0.05)$. The assessment of selected antioxidant gene expression showed that the $5 \%$ FL group significantly elevated heme oxygenase- 1 and nuclear factor erythroid 2 -related factor 2 expression, compared to the control and WB groups $(p<0.05)$. Furthermore, both of the FL supplemented groups had a significantly higher expression of glutathione peroxidase and catalase, compared to that of the WB and control groups in the jejunum $(p<0.05)$. The TJ mRNA expression in the jejunum showed that $5 \%$ FL significantly elevated the zonula occludens-1, claudin- 1 , and mucin-2 expression ( $p<0.05$ ), while 5\% and 10\% FL supplementation significantly improved OCLN expression in both the jejunum and ileum, compared to control group $(p<0.05)$. The intestinal morphology of 35-day-old broilers showed that a 5\% FL supplementation significantly increased the villus height in the ileum and jejunum, compared to the WB and control groups $(p<0.05)$. Moreover, the $5 \%$ and $10 \%$ FL supplementation groups had a significantly higher villi:crypt ratio in the ileum, compared to the WB and control groups $(p<0.05)$. To conclude, FL supplementation improved the antioxidative status, the TJ mRNA expression, and the intestinal morphology, and it was accompanied by a lowered feed conversion ratio in broilers. Finally, 5\% supplementation had the overall best results in improving the antioxidant status, TJ mRNA expression, and intestinal morphology of broilers.

Keywords: Laetiporus sulphureus; broiler chickens; antioxidant; tight junction; intestinal morphology 


\section{Introduction}

Oxidative damage is a critical problem in the poultry industry. It occurs when exogenously- and/or endogenously-produced Reactive Oxygen Species (ROS) exceed the antioxidant capacity of cells and extracellular spaces, causing the disruption of the normal cellular function by influencing the gene expression and signal transduction [1]. World poultry populations are mainly located in tropical and subtropical regions, where heat stress is a main concern, as it negatively influences the antioxidant status, which is reflected by the increased serum lipid peroxidation and reduced plasma concentrations of antioxidants [2]. These stress factors affect the health status of poultry and the safety of poultry products, while they adversely influence the intestinal oxidative status and disrupt the normal function of enterocytes, causing an abnormality in nutrient absorption and diseases [3]. As a consequence of suppressed nutrient absorption, the production indexes (such as feed efficiency and survival rate) are impaired, leading to heavy economic losses to the poultry industry [4].

Tight Junctions (TJs) are intercellular junctional complexes that maintain epithelial cells adherent to each other and guarantee the paracellular transportation of nutrients, forming a barrier between the lumen and host to prevent bacterial translocation [3]. The disruption of TJ impaired the normal intestinal function causing leaky gut that compromises the absorption of luminal substances into the bloodstream and could lead to chronic inflammation with impairment of animal health and growth performances [5]. Furthermore, the increased intestinal permeability could induce bacterial translocation, and a systemic bacterial infection might also occur [6]. Therefore, protecting the intestinal tract from excessive oxidative damage and maintaining the integrity of the TJ could be major factors that positively influence the performance of birds in the intensive poultry industry [4,7].

Agricultural by-products, such as Wheat Bran (WB), contain Non-Starch Polysaccharides (NSPs) that act as anti-nutritional compounds in monogastric animals, which tend to inhibit digestibility and promote pathogen proliferation in the gastrointestinal tract, and eventually lead to gut inflammation and worsen the performance of the animals [8,9]. Solid-State Fermentation (SSF) could represent a valuable method to use agricultural byproducts as substrates for NSP-degrading microorganisms, converting them into alternative feed ingredients $[10,11]$. In addition, filamentous fungi were reported as being a suitable inoculant for SSF due to their ability to withstand low humidity environments [11,12]. WB, a solid-state that is fermented by the Trichoderma sp., has been shown to exhibit antioxidant properties and to improve the nutrition value of $\mathrm{WB}$, which could potentially be a low-cost feedstuff candidate $[13,14]$. Solid-state WB fermented by Antrodia cinnamomea was found to be suitable for producing bioactive compounds, such as phenolics, triterpenoids, and polysaccharides, as well as for growth promotion and its antioxidative and anti-inflammatory effects in broiler feeding trials $[11,15]$. According to these studies, the use of fungal SSF in agricultural by-products is viable for producing functional feedstuffs that contain bioactive compounds.

The Laetiporus sp. is a fungal species with medical properties, and it was traditionally used by Europeans to cure gastric cancer, rheumatism, pyretic diseases, and coughs [16]. In our previous studies, we showed that L. sulphureus fermented WB and potentially enhanced the growth performance of broilers by modifying their intestinal microflora and their immune status [17]. Furthermore, submerged mycelial cultures of L. sulphureus produce functional polysaccharides [18,19], as well as mycophenolic acids [20], and are able to dampen the excessive immune response of the selected cells without causing cytotoxicity [21,22]. Petrović et al. [23] reported that the aqueous extracts of wild L. sulphureus exert 1,1-diphenyl-2-picrylhydrazyl (DPPH) radical scavenging activity, which correlates with its total phenolic content. Our previous study also indicated the potential of L. sulphureus to produce various bioactive compounds, such as crude phenolics, crude triterpenoids, polysaccharides, and ergosterol. The same study also showed that ethanol extracts of L. sulphureus fermented WB significantly attenuated the DNA damage induced by 2,2'-Azobis (2-amidinopropane) dihydrochloride (AAPH) in peripheral blood mononu- 
clear cells of chickens, while exerting an in vitro antioxidant effect, including DPPH radical scavenging activity and reducing power [24]. However, the effects of L. sulphureus on the antioxidative status and TJ modulation in the gastrointestinal tracts of broilers has rarely been studied.

In order to evaluate the in vivo antioxidant properties of $L$. sulphureus solid-state fermented product (FL) in broiler chickens, nuclear factor erythroid 2-related factor 2 (Nrf2) and its downstream pathway was evaluated. Nrf2 is a redox-sensitive transcription factor that could be triggered by ROS, leading to the production of detoxification and antioxidant enzymes such as heme oxygenase-1 (HO-1), superoxide dismutase (SOD), catalase (CAT), and glutathione peroxidase (GPx) [2]. Therefore, this study was performed in order to evaluate if the in vitro antioxidant activity of FL could be used in vivo to improve the antioxidant status of broiler chickens and further investigated the effect of FL on broilers and the interaction between the antioxidation capacity and the expression of intestinal TJ mRNA.

\section{Materials and Methods}

\subsection{Laetiporus sulphureus Culture, Inoculum Preparation, and Solid-State Fermentation}

Methods for culturing L. sulphureus (Bull.) Murril and preparing FL were performed according to [17]. The L. sulphureus (Bull.) Murril used in this study was purchased from the Bioresource Collection and Research Center (BCRC, Hsinchu, Taiwan). The fungus was cultured on Malt Extract Agar (MEA) plates and incubated in a temperature-controlled incubator (PHCbi, Tokyo, Japan) at $25^{\circ} \mathrm{C}$, with a routine sub-cultivation (at a frequency of once per week). A solid-state fermentation inoculum was cultured in Erlenmeyer flasks containing $100 \mathrm{~mL}$ sterilized Malt Extract Broth (MEB). Five pieces of round-shaped agar (about $1 \mathrm{~cm}$ in diameter) were punched out from an L. sulphureus MEA plate and transferred to flasks containing $100 \mathrm{~mL}$ MEB. These flasks were incubated by a rotary shaker incubator (PHCbi, Tokyo, Japan) at $25^{\circ} \mathrm{C}$, at $120 \mathrm{rpm}$ for five days (d). The malt extract broth that was grown with L. sulphureus filaments was put in a sterilized plastic bag and homogenized with a Seward Stomacher (Seward Laboratory Systems Inc., NY, USA) for the preparation of the inoculum. Solid-state fermentation was performed by adjusting $50 \mathrm{~g}$ of WB to $50 \%$ moisture content by adding distilled water and contained in a plastic bag. After autoclaved at $121 \pm 1{ }^{\circ} \mathrm{C}$ for $30 \mathrm{~min}$, the plastic bags containing sterilized WB were added with $10 \mathrm{~mL}$ of inoculants and fermented aerobically at $25^{\circ} \mathrm{C}$ for 12 days. The fermented products were collected and dried at $40^{\circ} \mathrm{C}$ for 2 days before being ground in a mill for the subsequent preparation of experimental broiler feed.

\subsection{Experimental Birds and Housing}

The animal experiment was authorized by the Animal Care and Use Committee of the National Chung Hsing University, Taiwan (IACUC No. 105-140). Four-hundred oneday-old male broilers (Ross 308) were randomly allocated into the five experimental diets: (1) corn-soybean meal (control), (2) a basal diet replaced with 5\% WB (5\% WB), (3) a basal diet replaced with 10\% WB (10\% WB), (4) a basal diet replaced with 5\% FL (5\% FL), and (5) a basal diet replaced with 10\% FL (10\% FL), with four replicates (pen)/diet and 20 birds per pen (a total of 80 birds/treatment). The replacement of WB or FL in the basal diet means the feed formula had $5 \%$ or $10 \%$ of the experimental ingredients, and the nutrient value of feeds in each control and treatment groups were adjusted to meet the nutrient requirements of broilers, as recommended by the National Research Council (NRC) [25], while each group had the same amount of ME and crude protein contents (Tables 1 and 2). The experimental period included two phases: the starter phase (1-21 days) and the finisher phase (22-35 days), and provided to broilers without any anticoccidial or antibacterial supplements. The approximate composition, including crude protein, dry matter, and crude fat, was analyzed by following the method of the Association of Official Analytical Chemists (AOAC) [26] and demonstrated in our previous study [17] and shown in Table S1. At the start of the experiment, the average body weight of the birds was adjusted to make it 
uniform for all pens. The birds were kept in floor pens $(2.5 \times 4.0 \mathrm{~m})$ with concrete floors and rice hull. The chicks were vaccinated against infectious bronchitis and Newcastle disease immediately after birth. The broilers had free access to feed and water during the whole experimental period. On day 35, the performance of the broilers was assessed by recording their Body Weight Gains (BWG), Body Weight (BW), Feed Intake (FI), and Feed Conversion Ratio (FCR; feed intake/body weight gain). The data of growth performances were demonstrated in Table 3 of our previous publication [17].

\subsection{Collection of Serum, Intestinal Content, and Organs}

On day 35, a total of six birds were randomly selected from a total of 80 birds per control or treatment group for sampling. Five $\mathrm{mL}$ blood samples were collected from the brachial vein and centrifuged at $2000 \times g$ for $10 \mathrm{~min}$ in order to collect the serum samples. Subsequently, the chickens were euthanized by exsanguination, and the organs (liver, jejunum, and ileum) were harvested and submerged in RNA shield ${ }^{\mathrm{TM}}$ (ZYMO, Irvine, CA, USA) for mRNA isolation. All samples were stored at $-80^{\circ} \mathrm{C}$ until further analysis.

Table 1. Ingredients of the experimental diets for broilers at the starter phase (days 1-21).

\begin{tabular}{|c|c|c|c|c|c|}
\hline \multirow{2}{*}{ Ingredients } & \multicolumn{5}{|c|}{ Starter Phase (Days 1-21) } \\
\hline & Control & $5 \% \mathrm{WB}$ & $5 \% \mathrm{FL}$ & $10 \% \mathrm{WB}$ & $10 \% \mathrm{FL}$ \\
\hline & \multicolumn{5}{|c|}{$\mathrm{g} / \mathrm{kg}$} \\
\hline Corn & 524.9 & 458.7 & 458.4 & 392.5 & 391.9 \\
\hline WB & 0 & 50.0 & 0 & 100.0 & 0 \\
\hline FL & 0 & 0 & 50.0 & 0 & 100.0 \\
\hline Soybean meal, CP 44\% & 320.0 & 167.3 & 167.3 & 14.8 & 14.7 \\
\hline Fish meal, CP $60 \%$ & 50.0 & 50.0 & 50.0 & 50.0 & 50.0 \\
\hline Full fat soybean meal & 41.4 & 209.8 & 210.1 & 377.9 & 378.7 \\
\hline Soybean oil & 30.0 & 30.0 & 30.0 & 30.0 & 30.0 \\
\hline Limestone & 11.6 & 11.6 & 11.6 & 11.5 & 11.5 \\
\hline Monocalcium phosphate & 11.2 & 11.2 & 11.2 & 11.2 & 11.2 \\
\hline DL-Methionine & 3.4 & 3.7 & 3.7 & 4.1 & 4.1 \\
\hline Sodium chloride & 2.9 & 2.8 & 2.8 & 2.8 & 2.8 \\
\hline L-Lysine $\mathrm{HCl}$ & 1.8 & 2.1 & 2.1 & 2.4 & 2.3 \\
\hline Choline- $\mathrm{Cl}(60 \%)$ & 0.8 & 0.8 & 0.8 & 0.8 & 0.8 \\
\hline Vitamin premix ${ }^{1}$ & 1.0 & 1.0 & 1.0 & 1.0 & 1.0 \\
\hline Mineral premix 2 & 1.0 & 1.0 & 1.0 & 1.0 & 1.0 \\
\hline Total & 1000.0 & 1000.0 & 1000.0 & 1000.0 & 1000.0 \\
\hline \multicolumn{6}{|l|}{ Calculated nutrient value } \\
\hline $\mathrm{ME}, \mathrm{kcal} / \mathrm{kg}$ & 3050.0 & 3050.0 & 3050.0 & 3050.0 & 3050.0 \\
\hline Dry matter, \% & 88.28 & 88.85 & 89.11 & 89.42 & 89.95 \\
\hline Crude protein, $\%$ & 23.0 & 23.0 & 23.0 & 23.0 & 23.0 \\
\hline Crude fat, $\%$ & 6.04 & 8.86 & 8.64 & 11.68 & 11.25 \\
\hline Calcium, \% & 1.05 & 1.05 & 1.05 & 1.05 & 1.05 \\
\hline Total phosphorus, \% & 0.73 & 0.73 & 0.73 & 0.72 & 0.72 \\
\hline Available phosphorus, $\%$ & 0.50 & 0.50 & 0.50 & 0.50 & 0.50 \\
\hline Lysine, $\%$ & 1.43 & 1.43 & 1.43 & 1.43 & 1.43 \\
\hline Methionine, $\%$ & 0.73 & 0.74 & 0.74 & 0.76 & 0.76 \\
\hline Cysteine, \% & 0.34 & 0.32 & 0.32 & 0.31 & 0.31 \\
\hline $\begin{array}{l}\text { WB: wheat bran; FL: Laetiporus } \\
\text { D3, } 3000 \mathrm{U} \text {; Vit. E, } 30 \mathrm{mg} \text {; Vit. } \\
19 \mathrm{mg} \text {; Niacin, } 50 \mathrm{mg} \text {; Folic aci } \\
\left(\mathrm{CuSO}_{4} \cdot 5 \mathrm{H}_{2} \mathrm{O}\right), 10.8 \mathrm{mg} \text {; Fe (Fe } \\
0.18 \mathrm{mg} .\end{array}$ & ureus fer & $\begin{array}{l}\text { wheat br } \\
3 \mathrm{mg} ; \mathrm{Py} \\
\text { tg. }{ }^{2} \mathrm{Su}\end{array}$ & applied & of diet: $\mathrm{Vi}$ & $\begin{array}{l}15000 \mathrm{U} ; \\
\text { antothen } \\
255 \mathrm{mg} \text {; }\end{array}$ \\
\hline
\end{tabular}


Table 2. Ingredients of the experimental diets for broilers at the finisher phase (days 22-35).

\begin{tabular}{|c|c|c|c|c|c|}
\hline \multirow{3}{*}{ Ingredients } & \multicolumn{5}{|c|}{ Finisher Phase (Days 22-35) } \\
\hline & Control & $5 \% \mathrm{WB}$ & $5 \% \mathrm{FL}$ & $10 \% \mathrm{WB}$ & $10 \% \mathrm{FL}$ \\
\hline & \multicolumn{5}{|c|}{$\mathrm{g} / \mathrm{kg}$} \\
\hline Corn & 549.5 & 482.9 & 482.9 & 416.3 & 416.3 \\
\hline WB & 0 & 50.0 & 0 & 100.0 & 0 \\
\hline FL & 0 & 0 & 50.0 & 0 & 100.0 \\
\hline Soybean meal, CP $44 \%$ & 16.6 & 185.6 & 185.6 & 354.4 & 354.4 \\
\hline Fish meal, CP 60\% & 320.6 & 167.8 & 167.8 & 15.1 & 15.1 \\
\hline Full fat soybean meal & 30.0 & 30.0 & 30.0 & 30.0 & 30.0 \\
\hline Soybean oil & 10.6 & 10.6 & 10.6 & 10.6 & 10.6 \\
\hline Limestone & 12.2 & 12.2 & 12.2 & 12.2 & 12.2 \\
\hline Monocalcium phosphate & 3.4 & 3.3 & 3.3 & 3.2 & 3.2 \\
\hline DL-Methionine & 50.0 & 50.0 & 50.0 & 50.0 & 50.0 \\
\hline Sodium chloride & 1.3 & 1.5 & 1.5 & 1.8 & 1.8 \\
\hline L-Lysine $\mathrm{HCl}$ & 3.0 & 3.3 & 3.3 & 3.6 & 3.6 \\
\hline Choline-Cl (60\%) & 0.8 & 0.8 & 0.8 & 0.8 & 0.8 \\
\hline Vitamin premix ${ }^{1}$ & 1.0 & 1.0 & 1.0 & 1.0 & 1.0 \\
\hline Mineral premix 2 & 1.0 & 1.0 & 1.0 & 1.0 & 1.0 \\
\hline Total & 1000.0 & 1000.0 & 1000.0 & 1000.0 & 1000.0 \\
\hline \multicolumn{6}{|l|}{ Calculated nutrient value } \\
\hline $\mathrm{ME}, \mathrm{kcal} / \mathrm{kg}$ & 3175.0 & 3175.0 & 3175.0 & 3175.0 & 3175.0 \\
\hline Dry matter, \% & 88.31 & 88.88 & 89.15 & 89.45 & 89.98 \\
\hline Crude protein, $\%$ & 21.0 & 21.0 & 21.0 & 21.0 & 21.0 \\
\hline Crude fat, $\%$ & 7.56 & 10.39 & 10.17 & 13.22 & 12.78 \\
\hline Calcium, $\%$ & 0.90 & 0.90 & 0.90 & 0.90 & 0.90 \\
\hline Total phosphorus, \% & 0.68 & 0.67 & 0.67 & 0.67 & 0.67 \\
\hline Available phosphorus, $\%$ & 0.45 & 0.45 & 0.45 & 0.45 & 0.45 \\
\hline Lysine, $\%$ & 1.25 & 1.25 & 1.25 & 1.25 & 1.25 \\
\hline Methionine, \% & 0.65 & 0.66 & 0.66 & 0.67 & 0.67 \\
\hline Cysteine, \% & 0.31 & 0.30 & 0.30 & 0.29 & 0.29 \\
\hline
\end{tabular}

WB: wheat bran; FL: Laetiporus sulphureus fermented product. ${ }^{1}$ Supplied per kg of diet: Vit. A, $15000 \mathrm{U}$; Vit. D3, 3000 U; Vit. E, 30 mg; Vit. K3, 4 mg; Riboflavin, 8 mg; Pyridoxine, 5 mg; Vit. B12, 25 g; Ca-pantothenate $19 \mathrm{mg}$; Niacin, $50 \mathrm{mg}$; Folic acid, $1.5 \mathrm{mg}$; Biotin, $60 \mu \mathrm{g}$. ${ }^{2}$ Supplied per $\mathrm{kg}$ of diet: $\mathrm{Co}\left(\mathrm{CoCO}_{3}\right), 0.255 \mathrm{mg}$; $\mathrm{Cu}$

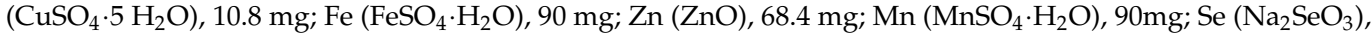
$0.18 \mathrm{mg}$.

\subsection{Determination of Serum Antioxidant Indexes}

The collected serum from each treatment group was analyzed for the antioxidant indexes, including the CAT, superoxide dismutase (SOD), GPx activity, and glutathione (GSH), glutathione disulfide (GSSG), and malondialdehyde (MDA) levels. The serum CAT activity was determined by using the Cayman Chemical Catalase Assay Kit (Cayman Co, Ann Arbor, MI, USA, item No. 707002), based on the method of Wheeler et al. [27]. The SOD activity was detected by modifying the method of Wheeler et al. [27], using the Superoxide Dismutase Assay Kit (Cayman Co, USA, item No. 706002). The MDA concentration was tested according to the method described by Yagi [28] by using the 2-thiobarbituric acid reacting substances (TBARS) Assay Kit (Cayman Co, Ann Arbor, MI, USA, item No. 10009055). The Glutathione Peroxidase Assay Kit (Cayman Co, Ann Arbor, MI, USA, item No. 703102) was used for the examination of GPx activity, according to the method of Paglia et al. [29]. The serum levels of GSH and GSSG in 35-day-old chickens were assayed by using the glutathione kit (Cayman Co, Ann Arbor, MI, USA, item No. 703002), based on the method of Baker et al. [30].

\subsection{RNA Extraction and Quantitative Reverse Transcription-Polymerase Chain Reaction}

Organ samples submerged in the RNA shield ${ }^{\mathrm{TM}}$ (ZYMO, USA) were processed to extract RNA, by following the commercial kit manual (AllBio Science, Inc., Taichung, Taiwan). After the extraction, the concentrations of RNA samples were determined spectrophoto- 
metrically and diluted to $50 \mathrm{ng} / \mu \mathrm{L}$. A quantitative real-time polymerase chain reaction (RT-qPCR) analysis was conducted by using the StepOnePlus ${ }^{\text {TM }}$ Real-Time PCR System (Roche Diagnostics Ltd., Taipei, Taiwan), according to the method of Lin et al. [31]. The primers that were applied in the experiment are provided in Table 3, based on the genes of Gallus gallus. The data of the gene expressions from the same treatment were normalized to $\beta$-actin (housekeeping gene). The means and Standard Deviation (SD) were calculated.

Table 3. Characteristrics and performance data of the primers used for RT-qPCR analysis.

\begin{tabular}{|c|c|c|}
\hline Genes & $\begin{array}{l}\text { Forward Primer (from } 5^{\prime} \text { to } 3^{\prime} \text { ) } \\
\text { Reverse Primer (from } 5^{\prime} \text { to } 3^{\prime} \text { ) }\end{array}$ & NCBI GenBank \\
\hline$\beta$-actin & $\begin{array}{l}\text { CTGGCACCTAGCACAATGAA } \\
\text { ACATCTGCTGGAAGGTGGAC }\end{array}$ & X00182.1 \\
\hline $\mathrm{HO}-1$ & $\begin{array}{l}\text { AGCTTCGCACAAGGAGTGTT } \\
\text { GGAGAGGTGGTCAGCATGTC }\end{array}$ & X56201.1 \\
\hline$S O D$ & $\begin{array}{l}\text { GCCACCTACGTGAACAACCT } \\
\text { AGTCACGTTTGATGGCTTCC }\end{array}$ & NM_204211.1 \\
\hline Nrf2 & $\begin{array}{l}\text { GGAAGAAGGTGCTTTTCGGAGC } \\
\text { GGGCAAGGCAGATCTCTTCCAA }\end{array}$ & NM_205117.1 \\
\hline$C A T$ & $\begin{array}{l}\text { CCACGTGGACCTCTTCTTGT } \\
\text { AAACACTTTCGCCTTGCAGT }\end{array}$ & NM_001031215.1 \\
\hline$G P x$ & $\begin{array}{l}\text { CAGCAAGAACCAGACACCAA } \\
\text { CCAGGTTGGTTCTTCTCCAG }\end{array}$ & NM_001163245.1 \\
\hline $\mathrm{ZO}-1$ & $\begin{array}{l}\text { AGGTGAAGTGTTTCGGGTTG } \\
\text { CCTCCTGCTGTCTTTGGAAG }\end{array}$ & XM_015278975.1 \\
\hline$C L D N-1$ & $\begin{array}{l}\text { GGAGGATGACCAGGTGAAGA } \\
\text { TCTGGTGTTAACGGGTGTGA }\end{array}$ & NM_001013611.2 \\
\hline MUC-2 & $\begin{array}{l}\text { GCTACAGGATCTGCCTTTGC } \\
\text { AATGGGCCCTCTGAGTTTTT }\end{array}$ & NM_001318434.1 \\
\hline OCLN & $\begin{array}{l}\text { GTCTGTGGGTTCCTCATCGT } \\
\text { GTTCTTCACCCACTCCTCCA }\end{array}$ & NM_205128.1 \\
\hline
\end{tabular}

RT-qPCR: real-time quantitative polymerase chain reaction; NCBI: National Center for Biotechnology Information HO-1: Heme oxygenase -1; SOD: Superoxide dismutase, mitochondrial; Nrf2: Nuclear factor (erythroid-derived 2)-like 2; CAT: catalase; GPX: Glutathione peroxidase; ZO-1: Zonula occludens-1; CLDN-1: Claudin-1: MUC-2: Mucin 2; OCLN: Occludin.

\subsection{Intestinal Morphology Evaluation}

The jejunum (from the pancreatic loop to Meckel's diverticulum) and ileum (from Meckel's diverticulum to the ileo-caeco-colic junction) samples from each bird (approximately $3 \mathrm{~cm}$ ) were collected and fixed in 10\% formalin. After washing them in a phosphate buffer saline solution and including them in paraffin wax, samples were cut at a thickness of $3 \mu \mathrm{m}$ and stained with hematoxylin and eosin. The Motic image plus 2.0 (Motic Inc., Schertz, TX, USA), combined with light microscopy, was applied for the measurement of the villus height and crypt depth. Twenty spots of villi and crypt from the intestinal samples from six birds in each control and treatment groups were measured and calculated for the ratio of the villus height to the crypt depth.

\subsection{Statistical Analysis}

Data were subjected to analysis of variance (ANOVA) as a completely randomized design by using the generalized linear model (GLM) function in the SAS software (SAS $9.4,2018)$. Normality of data distribution was checked, significant statistical differences were determined among the various treatment group means, using Tukey's honest significant difference test. The effects of the experimental diet on the response variables were considered to be significant at $p<0.05$. 


\section{Results}

\subsection{Growth Performance}

The growth performances of one- to 35-day-old broilers were demonstrated in Table 3 of our previous publication [17]. No significant difference was observed in the body weight, body weight gain, and feed intake of each group of 1-35 day-old broilers and 1-21 day-old broilers $(p>0.05)$. While $5 \%$ FL group had significantly higher BW than the control group and $10 \%$ WB group during $22-35 \mathrm{~d}$. The FCR of $5 \%$ and $10 \%$ FL supplemented groups (both 1.41) were significantly lower than that in the control group (1.47), as well as in the $5 \%$ and $10 \%$ WB groups (1.45 and 1.46 , respectively) $(p<0.05)$.

\subsection{Serum Antioxidant Profiles}

The serum antioxidant profiles of 35-day-old broilers supplemented with FL are presented in Table 4. Compared to the control group, $5 \%$ and $10 \% \mathrm{WB}$ group, the $5 \% \mathrm{FL}$ supplementation significantly improved SOD activity, while the concentration of MDA in the serum was down-regulated $(p<0.05)$. However, there was no significant difference in the indexes, including the CAT activity, GPx activity, GSH concentration, GSSG concentration, and GSH:GSSG $(p>0.05)$.

Table 4. Effects of FL supplementation on serum antioxidant profiles in 35-day-old broilers ${ }^{1}$.

\begin{tabular}{|c|c|c|c|c|c|c|c|}
\hline \multirow{2}{*}{ Items } & \multicolumn{5}{|c|}{ Treatments } & \multirow{2}{*}{ SEM } & \multirow{2}{*}{$p$-Values } \\
\hline & Control & $5 \% \mathrm{WB}$ & $10 \% \mathrm{WB}$ & $5 \% \mathrm{FL}$ & $10 \% \mathrm{FL}$ & & \\
\hline $\mathrm{SOD}(\mathrm{U} / \mathrm{mL})$ & $9.18^{b c}$ & $9.36^{b}$ & $8.96^{c}$ & $9.82^{a}$ & $9.40^{b}$ & 0.05 & 0.001 \\
\hline CAT (U/mL) & 15.35 & 15.82 & 15.57 & 15.81 & 15.53 & 0.11 & 0.86 \\
\hline $\operatorname{MDA}(\mu \mathrm{M})$ & $28.52^{\mathrm{a}}$ & $25.76^{b}$ & $29.66^{a}$ & $23.53^{c}$ & $24.17^{b c}$ & 0.21 & $<0.0001$ \\
\hline GPx $(\mathrm{U} / \mathrm{mL})$ & $146.42^{\mathrm{ab}}$ & $148.14^{\mathrm{a}}$ & $141.51^{b}$ & $151.66^{\mathrm{a}}$ & $151.13^{a}$ & 0.84 & 0.005 \\
\hline GSH (mg/mL) & 2.01 & 2.17 & 2.13 & 2.21 & 2.19 & 0.04 & 0.71 \\
\hline GSSG (mg/mL) & 0.11 & 0.12 & 0.14 & 0.13 & 0.11 & 0.005 & 0.72 \\
\hline GSH:GSSG & 20.65 & 19.14 & 16.52 & 21.08 & 21.71 & 0.65 & 0.51 \\
\hline
\end{tabular}

${ }^{1}$ The results are expressed as the means of six replicates in each control and treatment group. SEM: Standard Error of the Mean. WB: Wheat Bran; FL: Laetiporus sulphureus fermented product; SOD: Superoxide dismutase; CAT: catalase; MDA: malondialdehyde; GPx: glutathionine peroxidase; GSH: Glutathione; GSSG: oxidized glutathione. ${ }^{a-c}$ Means within the same rows, but without the same superscript letter, are significantly different $(p<0.05)$.

\subsection{Expression of Selected Antioxidant Genes}

The expression profile of selected antioxidant genes in the liver, jejunum, and ileum are displayed in Figure 1. Both FL groups had a significantly elevated HO-1 and SOD expression in the liver, jejunum, and ileum, compared to those in the control group $(p<0.05)$. Furthermore, the 5\% FL group had a significantly elevated HO-1 and Nrf2 expression in the liver and jejunum, compared to those in WB and control groups $(p<0.05)$. In addition, the $5 \%$ FL supplementation group had a significantly elevated expression of Nrf2 in the jejunum, compared to the control and WB groups $(p<0.05)$. In the liver, there was no significant change in the CAT and GPx mRNA expression of each group ( $p>0.05)$, while no significant differences between $10 \%$ FL vs. $5 \%$ WB and $10 \%$ WB as well as $5 \%$ FL vs. $10 \%$ FL in the relative mRNA expression of $H O-1$. The FL groups had a significantly better expression of GPx and CAT, compared to those in the jejunum of the WB and control groups $(p<0.05)$. However, there was no significant difference among each group for Nrf2, GPx, and CAT expression in the ileum, while mRNA expression of HO- 1 in both FL groups was not significantly different from the $5 \% \mathrm{WB}$ group $(p>0.05)$. Both FL groups showed no significant difference in the mRNA expression of $S O D$ compared to the WB groups in the ileum $(p>0.05)$. 
(A)

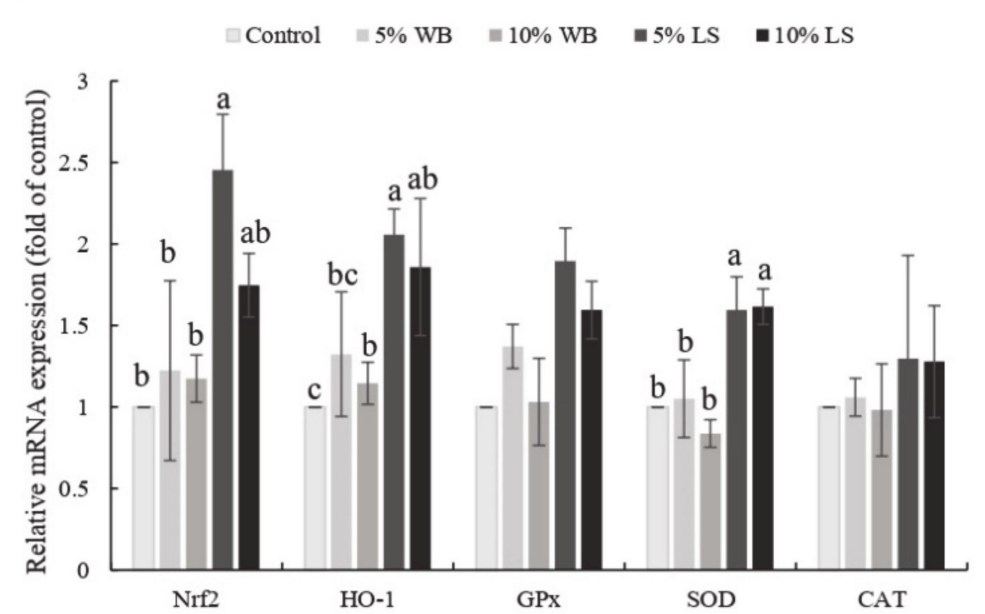

(B)

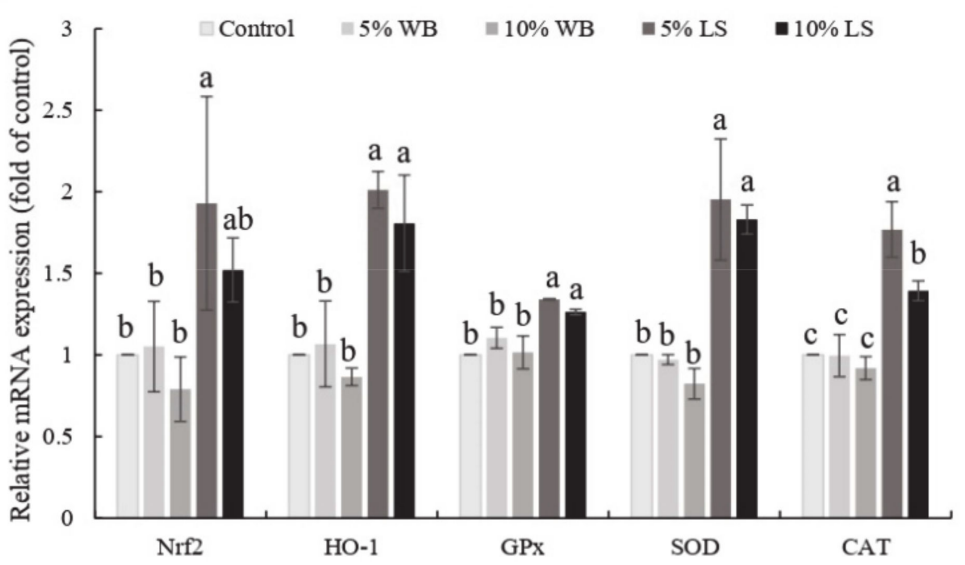

(C)

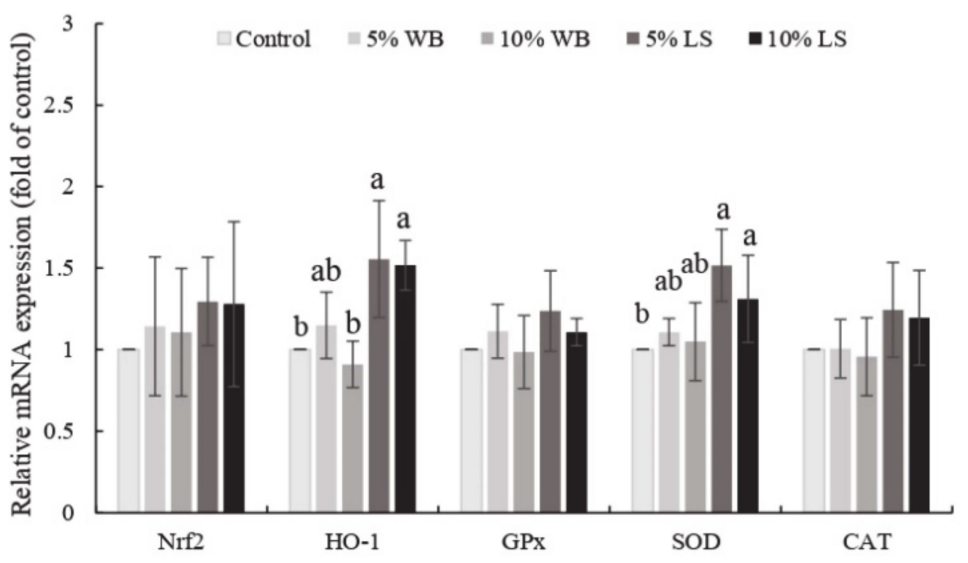

Figure 1. Effects of FL supplementation on mRNA expression levels of the selected genes related to antioxidant-status in (A) liver, (B) jejunum, and (C) ileum of 35-day-old broilers. Values are expressed as the mean \pm standard deviation $(n=6) .{ }^{\text {a-c }}$ Means among groups without the same letter, within the same sampling day, are significantly different $(p<0.05)$. WB: Wheat Bran; FL: Laetiporus sulphureus fermented product. 


\subsection{Selected Tight Junction (TJ) Gene Expression}

The effects of FL on selected TJ mRNA expressions are presented in Figure 2. Wheat bran supplementation in broilers had no significant effect on the expression of selected TJ mRNA in both the jejunum and the ileum $(p>0.05)$. Tight junction mRNA expressions in the jejunum showed that the $5 \%$ FL group had significantly elevated CLDN-1 expression, compared to the control and WB groups, while both FL supplementations significantly improved the expression of OCLN in the jejunum and ileum $(p<0.05)$. A significantly higher MUC-2 expression in the jejunum and ileum was observed only in the 5\% FL supplemented group, compared to that in the control group $(p<0.05)$. In addition, $5 \%$ and $10 \%$ FL supplementation significantly improved the expression of ZO-1 in jejunum and ileum, compared to that in the $5 \%$ and $10 \% \mathrm{WB}$ groups $(p<0.05)$. However, there were no significant differences among the groups in terms of the ileal expression of CLDN-1 $(p>0.05)$.
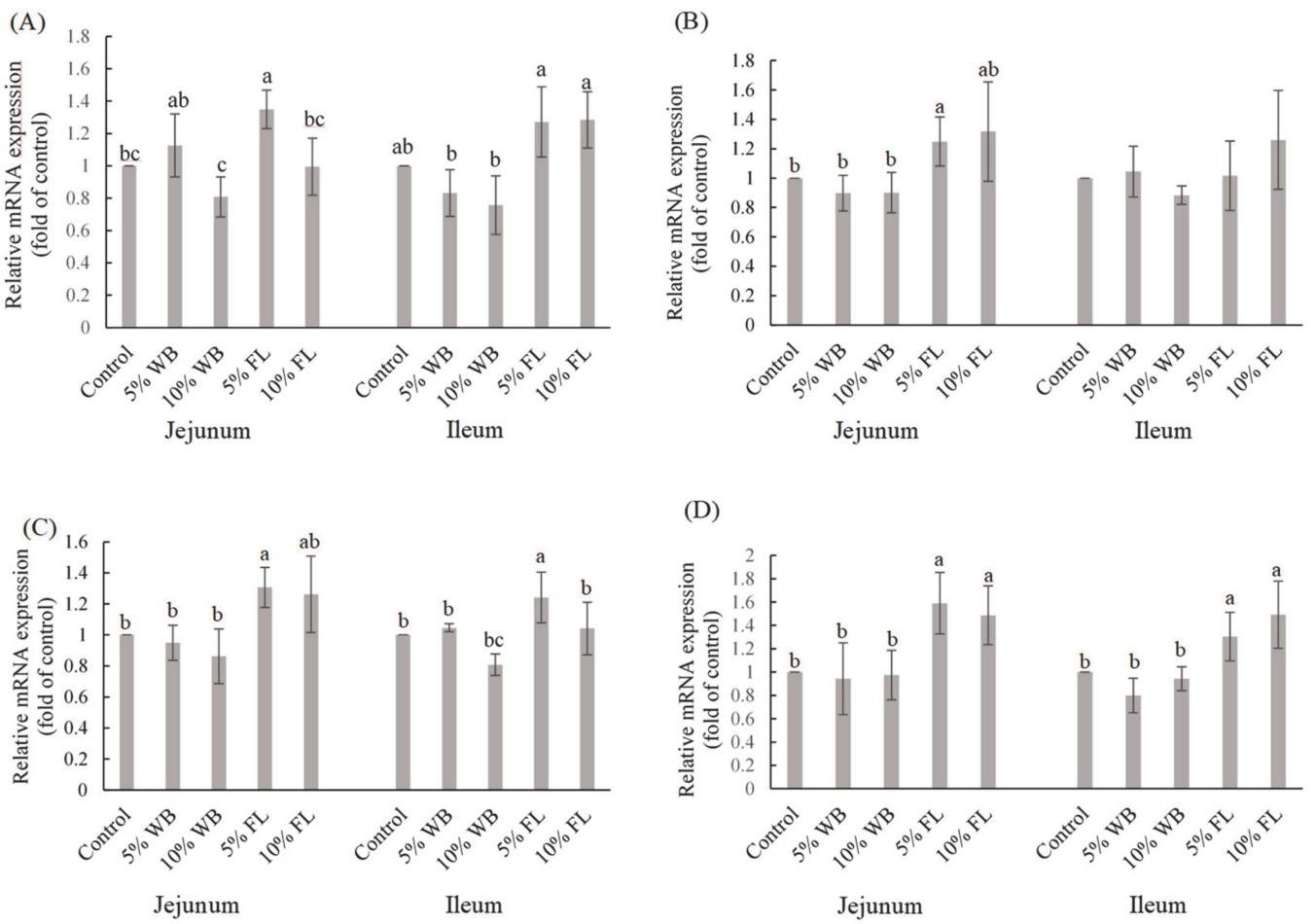

Figure 2. The effects of FL supplementation on ZO-1 (A), CLDN-1 (B), MUC-2 (C), and OCLN (D) mRNA expression in the jejunum and ileum of 35-d-old broiler chickens. Values are expressed as the mean \pm standard deviation $(n=6)$. ${ }^{\mathrm{a}-\mathrm{c}}$ Means within the same rows, without the same superscript letter, are significantly different $(p<0.05)$. WB: Wheat Bran; FL: Laetiporus sulphureus fermented product; ZO-1: Zonula occludens-1; CLDN-1: Claudin-1: MUC-2: Mucin-2; OCLN: Occludin.

\subsection{Intestinal Morphology}

The changes in intestinal morphology of 35-day-old broilers in each control and treatment group are listed in Table 5 . The results show that $5 \%$ FL supplementation significantly increased the villus height in the ileum and jejunum, compared to those in the WB and control groups, while both FL supplementation groups had significantly higher villus in the jejunum, compared to the $10 \% \mathrm{WB}$ group $(p<0.05)$. Furthermore, the jejunal and ileal crypt depth in the 10\% FL group was significantly reduced compared to that of the control group $(p<0.05)$. A significantly higher villi:crypt ratio in the ileum was observed in the FL groups, compared to that in the WB and control groups $(p<0.05)$. However, the villi:crypt ratio in the jejunum of both FL groups was not significantly different from that in the control and WB groups $(p>0.05)$. The microscopic images of the jejunum and ileum sections are displayed in Figure 3. 
Table 5. Effects of FL supplementation on intestinal morphology in 35-day-old broilers 1.

\begin{tabular}{|c|c|c|c|c|c|c|c|}
\hline \multirow{2}{*}{ Items } & \multicolumn{5}{|c|}{ Treatments } & \multirow{2}{*}{ SEM } & \multirow{2}{*}{$p$-Values } \\
\hline & Control & $5 \% \mathrm{WB}$ & $10 \% \mathrm{WB}$ & $5 \% \mathrm{FL}$ & $10 \% \mathrm{FL}$ & & \\
\hline \multicolumn{8}{|c|}{ Jejunum } \\
\hline Villus height $(\mu \mathrm{m})$ & $1210.72^{b c}$ & $1207.34^{b c}$ & $1157.55^{c}$ & $1325.91^{a}$ & $1255.74^{\mathrm{ab}}$ & 10.29 & 0.001 \\
\hline Crypt depth & $270.72^{\mathrm{a}}$ & $203.38^{c}$ & $216.52 b c$ & $244.50^{\mathrm{ab}}$ & $212.41^{b c}$ & 5.28 & 0.002 \\
\hline Villi:crypt ratio & 5.10 & 5.98 & 5.52 & 5.78 & 5.96 & 0.12 & 0.16 \\
\hline \multicolumn{8}{|c|}{ Ileum } \\
\hline Villus height & $1058.68^{b}$ & $1118.71^{b}$ & $1032.24^{b}$ & $1126.53^{a}$ & $113047^{a}$ & 8.10 & 0.04 \\
\hline Crypt depth & $198.27^{a}$ & $190.01^{\mathrm{ab}}$ & $188.03^{\mathrm{ab}}$ & $178.80^{\mathrm{ab}}$ & $170.71^{b}$ & 2.23 & 0.04 \\
\hline Villi:crypt ratio & $5.98^{\mathrm{b}}$ & $5.99^{b}$ & $5.51^{\mathrm{b}}$ & $6.50^{\mathrm{a}}$ & $6.24^{\mathrm{a}}$ & 0.07 & 0.03 \\
\hline
\end{tabular}

${ }^{1}$ The results are presented as the means of twenty spots corresponding to six birds each for the control and treatment groups. WB: Wheat Bran; FL: Laetiporus sulphureus fermented product; SEM: standard error of the mean. ${ }^{a-c}$ Means within the same rows, without the same superscript letter, are significantly different $(p<0.05)$.
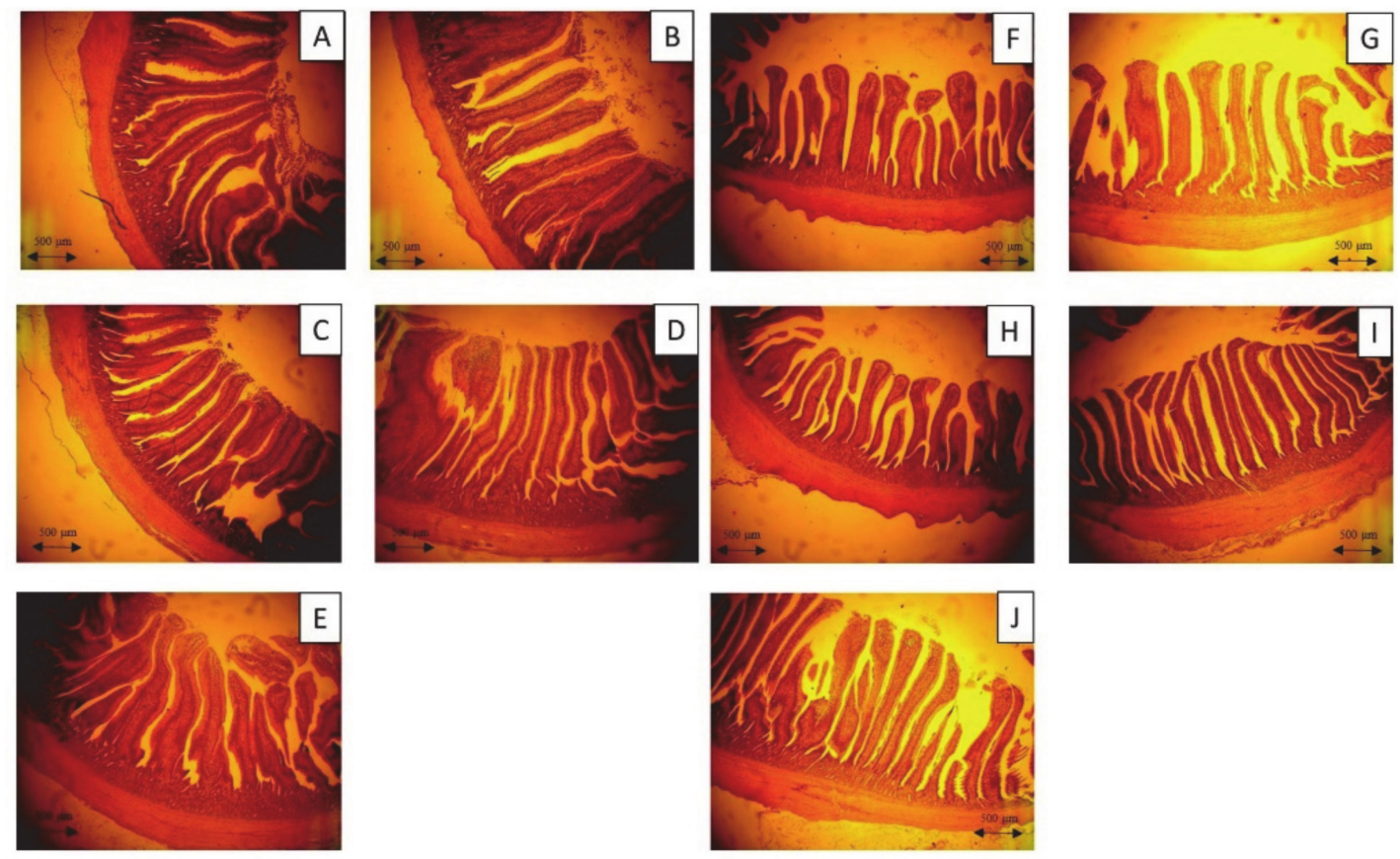

Figure 3. Photomicrography of the jejunum and ileum of 35-day-old broiler fed with control diet and Laetiporus sulphureus fermented product. (A)-(E) - the jejunum of 35-day-old broilers representing the control, 5\% WB, 10\% WB, 5\% FL, and $10 \%$ FL groups, respectively. (F)-(J) - the ileum of 35-day-old broilers representing the control, 5\% WB, 10\% WB, 5\% FL, and $10 \%$ FL groups, respectively. Haematoxylin and eosin stain $(40 \times)$.

\section{Discussion}

In order to evaluate the in vivo antioxidant properties of FL in broiler chickens, we focused on $N r f 2$ and its downstream pathway. In this study, the expression of Nrf2, HO-1, and SOD mRNAs in FL supplemented groups were up-regulated in the liver and jejunum, compared to those in the control group, which indicates the antioxidant role of FL in broilers. Nrf2 is a redox-sensitive transcription factor that is localized in the cytoplasm and binds with Kelch-like ECH-associated protein 1 (Keap 1), an actin-binding protein, under normal conditions [32]. Upon activation by ROS, Nrf2 dissociates from Keap 1, interacts with the antioxidant response elements, and regulates the expression of downstream antioxidant genes to activate the antioxidant and detoxifying effects [2]. The induction of HO-1 is an important cellular process for dealing with oxidative stress by degrading the intracellular levels of pro-oxidant heme and by producing biliverdin (a precursor of 
bilirubin) [33]. The elevated antioxidative status of FL supplemented groups could be due to the bioactive phenolic compounds within FL. The phenolic compounds derived from fungus have been reported to activate the Nrf2-Keap1 pathway in a suppressed Nrf2 diabetic rat model [34]. Furthermore, A. cinnamomea, a brown-rot fungus that exerted medicinal effects similar to those of L. sulphureus, reported the enhanced expression of Nrf2, HO-1, and SOD mRNAs in the liver of 35-day-old chickens fed upon its fermented feedstuff, as well as a further increase in SOD activity in the serum [11,15]. Therefore, it can be validated that $\mathrm{FL}$, as a medicinal fungus fermented products, may have also improved the antioxidative status of broilers via a similar mechanism as reported by above mentioned previous studies.

Non-enzymatic and enzymatic antioxidant systems are two strategies that are used in cells to inhibit the potential ROS toxicity. Enzymatic antioxidants are endogenously synthesized and regulated, which is a crucial indicator for evaluating the oxidative status of animal tissues [11,15]. SOD is an endogenous antioxidant enzyme that catalyzes the dismutation of $\mathrm{O}^{2-}$ to $\mathrm{H}_{2} \mathrm{O}_{2}$ and $\mathrm{O}_{2}$. In our study, the elevated SOD activity in the 5\% FL supplemented group indicated an increase in the extracellular antioxidant enzymatic activity. Similarly, Lin et al. [35] observed that the dietary supplementation of mulberry leaves improved the serum SOD levels and showed that these outcomes were due to the presence of abundant phenolic compounds in the tested product, which was in common with FL that consisted of phenolic compounds that exerted antioxidant ability. The development of oxidative injury could be indicated by the serum concentration of MDA because it is one of the end products of lipid peroxidation [36]. In this study, the FL-supplemented groups had a higher SOD activity and a lower MDA concentration. The elevated expression of serum SOD and HO-1 mRNA enhanced the capacity of broilers to catalyze the harmful radicals and encounter potential oxidative damage, which further led to the reduction of MDA in the serum, which represents a total decline in the lipid oxidation in animals. Likewise, Lee et al. [11] reported that the A. cinnamomea-fermented product supported the antioxidant status of broiler chickens by improving the SOD activities. Furthermore, the enzyme powder fermented by Trichoderma pseudokoningii was also found to exert an antioxidant effect on broiler chickens, which increased the serum SOD activities and reduced the MDA concentration [14]. Interestingly, FL seemed to have a less-pronounced effect on the ileum, which might be due to the direct absorbance of a simple-structured polyphenol in the jejunum, while the remaining complicated polyphenols are more likely to be fermented in the hindgut by cecal microbiota and to exert their bio-functional effects [37].

According to the results of this study, the increased mRNA expression of transmembrane proteins claudin-1 (CLDN-1), occludin (OCLN), and mRNA of peripheral membrane protein zonula occluden-1 (ZO-1) may be caused by the enhancement of the antioxidative status in the jejunum of the FL-supplemented groups. By improving the function of TJ and eliminating the deleterious effects of oxidative stress, the increase in MUC-2 mRNA expression could lead to the improved health condition of intestinal goblet cells. The integrity of epithelial cells and the normal function of the intestine in broiler chickens is maintained by the TJs, which consist of several crucial elements, including occludin, claudins, and ZOs. OCLN translates to occludin that forms the TJs, and its sealing property is involved in the hurdle functions of the epithelial barrier [38]. Claudins (translated from $C L D N$ ) are another family of integral membrane proteins that collaborate with occludin to maintain the integrity of the TJs [5]. ZO-1 and ZO-2 bind directly to the $\mathrm{COOH}$ terminus of the intracellular domain of occludin, which contributes to the normal structure of the epithelial barrier function [6]. In addition, the MUC-2 gene is expressed by goblet cells, which produce a mucus layer that helps in blocking pathogens invasion along with TJs [39]. The TJs could be disturbed when animals encounter heat stress and oxidative damage due to excessive free radicals, which could lead to leaky gut and onset of inflammatory response with poor animal health and impaired growth performances as a consequence. Moreover, MUC-2 deficiency in mice causes spontaneous inflammation and allows the colonization of unusual commensal bacteria [40]. The interaction of the antioxidant sta- 
tus and TJ integrity has also been proven in several studies by using various animals and cell models. Chen et al. [9] reported that riboflavin deprivation decreased the antioxidant enzyme activities, such as SOD, GPx, and glutathione reductase activities in young grass carp, which further reduced the expression of TJ mRNA, OCLN, and ZO-1. Zhao et al. [41] reported that the MUC-2 function could be interrupted by bisphenol A, which induces mitochondrial dysfunction and oxidative stress. Exogenous antioxidants, including polyphenols and polysaccharides, help to scavenge the excessive free radicals and prevent oxidative damage to the intestinal cells and proteins [42]. In an $\mathrm{H}_{2} \mathrm{O}_{2}$-induced oxidative damaged Caco-2 cell model, a phytogenic called red-osier dogwood, which contained abundant phenolic compounds, was introduced to enhance the expression of $\mathrm{HO}-1$, $S O D, G P x$ genes, and the Nrf2 protein, while improving the cell-integrity by increasing the expression of ZO- 1 and claudin-3 that were damaged by $\mathrm{H}_{2} \mathrm{O}_{2}$. In addition, Sun et al. [43] demonstrated that the essential oil cinnamaldehyde exerted an antioxidant activity and elevated the protein expression of claudin-4, occluding, and ZO-1. Chitosan oligosaccharide, an antioxidant and an immunomodulatory substance, has been proven to improve OCLN mRNA expression in the jejunum of broilers, while an increase in antioxidant enzymes and reduced levels of proinflammatory cytokine IL-6 were also observed [44]. Quercetin, an antioxidant flavonoid, was demonstrated to increase MUC-2 gene expression in human intestinal goblet cell-like LS174T [45]. Therefore, the improvement of the MUC-2 status in broilers supplemented with FL could result in the elevation of TJ integrity.

The villus height and crypt depth, with respect to the morphologies of the jejunum and ileum of broilers, are always used as an indicator of intestinal health. The villus height represents nutrient absorption efficiency, and a low crypt depth is favored, due to the reduced intestinal cell turnover rate, to save energy and achieve a better growth performance $[46,47]$. In our previous study, lignocellulose enzymes (laccase and xylanase), which are capable of degrading the deleterious effects of NSP-rich WB, were produced during L. sulphureus fermentation [17]. The improved morphologies of the jejunum and ileum in broilers could be due to the lignocellulose in FL. Similar results were also demonstrated by Chu et al. [13], who observed a positive impact of Trichoderma fermented wheat bran on the intestinal morphology of broilers, while Lin et al. [14] showed that the T. pseudokoningii fermented enzyme powder that contains NSPase improved the intestinal morphology of broilers. Furthermore, FL was found to be rich in phenolic compounds and capable of exerting an antioxidant effect, thus preventing oxidative stress. In the lumen of the intestine, stressors, including pathogens and pro-oxidants, can cause dynamic changes in the intestinal mucosa due to the close proximity of the mucosal surface and the intestinal contents [1]. According to the outcomes of TJ and intestinal morphology, the antioxidant effect of FL could potentially protect the intestinal mucosa, as well as the integrity of epithelial cells, from oxidative damage. Similar results were shown by Viveros et al. [48], who suggested that the dietary grape pomace concentrate $(60 \mathrm{~g} / \mathrm{kg}$ in feed) that are rich in polyphenols could improve the ratio of villus height and crypt depth (villus height: crypt depth) and increased the feed efficiency of broilers. Likewise, Lai et al. [8] reported that fermentation of soybean hulls containing phenolic-rich residues of Pleurotus eryngii stalk increased the villus height/crypt depth in the ileum. In this study, FL improved the villi:crypt ratio in the ileum compared to the control and WB groups, while higher villi and less shallow crypts were discovered in both jejunum and ileum of 5\% FL group compared to the WB and control groups. These improvements in intestinal morphology could be possibly caused by the antioxidant effect along with the potential existence of NSP enzymes.

\section{Conclusions}

In conclusion, FL is capable of improving the FCR in broilers by improving the antioxidative status of broilers while and enhancing intestinal TJ mRNA expression while minimizing the negative effects of dietary NSP. In addition, 5\% FL supplementation had the 
best overall results in enhancing the serum SOD activity and antioxidant gene expression in the liver, jejunum, and ileum while improving the intestinal TJ mRNA expression.

Supplementary Materials: The following are available online at https:/ /www.mdpi.com/2076-261 5/11/1/149/s1, Table S1: Chemical composition of the experimental diets for broilers.

Author Contributions: Conceptualization, W.C.L. and T.T.L.; materials analysis, W.C.L.; methodology, W.C.L. and T.T.L.; investigation, W.C.L. and T.T.L.; writing-original draft preparation, W.C.L. and T.T.L.; writing-review and editing, W.C.L. and T.T.L. All authors have read and agreed to the published version of the manuscript.

Funding: This research received no external funding.

Institutional Review Board Statement: The study was conducted according to the guidelines of the Declaration of Helsinki, and approved by the Institutional Review Board (or Ethics Committee) of Animal Care and Use Committee of the National Chung Hsing University, Taiwan (IACUC No. 105-140, Jan 1, 2016).

Informed Consent Statement: Informed consent was obtained from all subjects involved in the study.

Data Availability Statement: The data presented in this study are openly available at 10.1016/ j.psj.2020.04.011., reference number [17].

Acknowledgments: The authors thank the Ministry of Science and Technology (MOST 109-2321-B005-016- and 109-2313-B-005-008-MY3) and the Integrative and Evolutionary Galliformes Genomics (iEGG) and Animal Biotechnology Center from The Feature Areas Research Center Program within the framework of the Higher Education Sprout Project by the Ministry of Education (MOE) in Taiwan to Tzu-Tai Lee.

Conflicts of Interest: The authors declare no conflict of interest.

$\begin{array}{ll}\text { Abbreviations } \\ \text { WB } & \text { Wheat bran } \\ \text { FL } & \text { L. sulphureus fermented product } \\ \text { TJ } & \text { Tight junction } \\ \text { NSPs } & \text { Non-starch polysaccharides } \\ \text { MEB } & \text { Malt extract broth } \\ \text { MEA } & \text { Malt extract agar } \\ \text { RT } & \text { Room temperature } \\ \text { DPPH } & \text { 1,1-diphenyl-2-picrylhydrazyl } \\ \text { BHT } & \text { Butylated hydroxytoluene } \\ \text { chPBMC } & \text { Chicken peripheral blood mononuclear cells } \\ \text { AAPH } & \text { 2,2'-Azobis (2-amidinopropane) dihydrochloride } \\ \text { LPS } & \text { Lipopolysaccharide } \\ \text { FCR } & \text { Feed conversion ratio } \\ \text { SOD } & \text { Superoxide dismutase } \\ \text { CAT } & \text { Catalase } \\ \text { MDA } & \text { Malondialdehyde } \\ \text { GPx } & \text { Glutathionine peroxidase } \\ \text { GSH } & \text { Glutathione } \\ \text { GSSG } & \text { Glutathione disulfide } \\ \text { HO-1 } & \text { Heme oxygenase -1 } \\ \text { Nrf2 } & \text { Nuclear factor (erythroid-derived 2)-like 2 } \\ \text { CAT } & \text { Catalase } \\ \text { GPx } & \text { Glutathione peroxidase } \\ \text { ZO-1 } & \text { Zonula occludens-1 } \\ \text { CLDN-1 } & \text { Claudin-1 } \\ \text { MUC-2 } & \text { Mucin-2 } \\ \text { OCLN } & \text { Occludin } \\ & \end{array}$




\section{References}

1. Giannenas, I.; Pappas, I.S.; Mavridis, S.; Kontopidis, G.; Skoufos, J.; Kyriazakis, I. Performance and antioxidant status of broiler chickens supplemented with dried mushrooms (Agaricus bisporus) in their diet. Poult. Sci. 2010, 89, 303-311. [CrossRef]

2. Sahin, K.; Orhan, C.; Smith, M.; Sahin, N. Molecular targets of dietary phytochemicals for the alleviation of heat stress in poultry. World's Poult. Sci. J. 2013, 69, 113-124. [CrossRef]

3. Zaviezo, R. Nutritional management of birds affected by heat. Rev. Indust. Avi. 1999, 46, 42-46.

4. Tellez, G., Jr.; Tellez-Isaias, G.; Dridi, S. Heat stress and gut health in broilers: Role of tight junction proteins. Adv. Food Technol. Nutr. Sci. Open J. 2017, 3, e1-e4.

5. Johansson, M.E.V.; Sjövall, H.; Hansson, G.C. The gastrointestinal mucus system in health and disease. Nat. Rev. Gastroenterol. Hepatol. 2013, 10, 352-361. [CrossRef]

6. Robinson, K.; Deng, Z.; Hou, Y.; Zhang, G. Regulation of the intestinal barrier function by host defense peptides. Front. Vet. Sci. 2015, 2, 57. [CrossRef]

7. Mujahid, A.; Pumford, N.R.; Bottje, W.; Nakagawa, K.; Miyazawa, T.; Akiba, Y.; Toyomizu, M. Mitochondrial Oxidative Damage in Chicken Skeletal Muscle Induced by Acute Heat Stress. J. Poult. Sci. 2007, 44, 439-445. [CrossRef]

8. Lai, L.P.; Lee, M.T.; Chen, C.S.; Yu, B.; Lee, T.-T. Effects of co-fermented Pleurotus eryngii stalk residues and soybean hulls by Aureobasidium pullulans on performance and intestinal morphology in broiler chickens. Poult. Sci. 2015, 94, 2959-2969. [CrossRef]

9. Chen, L.; Feng, L.; Jiang, W.-D.; Jiang, J.; Wu, P.; Zhao, J.; Kuang, S.-Y.; Tang, L.; Tang, W.-N.; Zhang, Y.-A.; et al. Dietary riboflavin deficiency decreases immunity and antioxidant capacity, and changes tight junction proteins and related signaling molecules mRNA expression in the gills of young grass carp (Ctenopharyngodon idella). Fish. Shellfish Immunol. 2015, 45, 307-320. [CrossRef]

10. Hölker, U.; Höfer, M.; Lenz, J. Biotechnological advances of laboratory-scale solid-state fermentation with fungi. Appl. Microbiol. Biotechnol. 2004, 64, 175-186. [CrossRef]

11. Lee, M.T.; Lin, W.C.; Lin, L.-J.; Wang, S.Y.; Chang, S.C.; Lee, T.-T. Effects of dietary Antrodia cinnamomea fermented product supplementation on antioxidation, anti-inflammation, and lipid metabolism in broiler chickens. Asian-Australas. J. Anim. Sci. 2020, 33, 1113-1125. [CrossRef] [PubMed]

12. Hernández, J.S.; Aguilera-Carbó, A.F.; Rodríguez Herrera, R.; Martínez, J.L.; Aguilar, C.N. Kinetic production of the anti-oxidant ellagic acid by fungal solid state culture. In Proceedings of the 10th International Chemical and Biological Engineering Conference; Portuguese Engineers Association: Lisboa, Portugal, 2008; pp. 1849-1854.

13. Chu, Y.T.; Lo, C.T.; Chang, S.C.; Lee, T.T. Effects of Trichoderma fermented wheat bran on growth performance, intestinal morphology and histological findings in broiler chickens. Ital. J. Anim. Sci. 2016, 16, 82-92. [CrossRef]

14. Lin, W.C.; Lee, M.T.; Lo, C.T.; Chang, S.C.; Lee, T.-T. Effects of dietary supplementation of Trichoderma pseudokoningii fermented enzyme powder on growth performance, intestinal morphology, microflora and serum antioxidantive status in broiler chickens Ital. J. Anim. Sci. 2017, 17, 153-164. [CrossRef]

15. Lee, M.T.; Lin, W.C.; Lin, L.-J.; Wang, S.Y.; Chang, S.C.; Lee, T.-T. Effects of dietary Antrodia cinnamomea fermented product supplementation on metabolism pathways of antioxidant, inflammatory, and lipid metabolism pathways-a potential crosstalk. Asian-Australas. J. Anim. Sci. 2020, 33, 1167-1179. [CrossRef]

16. Ríos, J.-L.; Andújar, I.; Recio, M.-C.; Giner, R.-M. Lanostanoids from Fungi: A Group of Potential Anticancer Compounds. J. Nat. Prod. 2012, 75, 2016-2044. [CrossRef]

17. Lin, W.; Lee, T.-T. Laetiporus sulphureus-fermented wheat bran enhanced the broiler growth performance by improving the intestinal microflora and inflammation status. Poult. Sci. 2020, 99, 3606-3616. [CrossRef]

18. Lung, M.Y.; Wei, Z.H. Production, purification and tumor necrosis factor- $\alpha$ (TNF- $\alpha$ ) release capability of exopolysaccharide from Laetiporus sulphureus (Bulliard: Fries) Bondartsev \& Singer in submerged cultures. Proc. Biochem. 2011, 46, 433-439.

19. Jayasooriya, R.G.; Kang, C.H.; Seo, M.J.; Choi, Y.H.; Jeong, Y.K.; Kim, G.Y. Exopolysaccharide of Laetiporus sulphureus var. miniatus downregulates LPS-induced production of $\mathrm{NO}, \mathrm{PGE}_{2}$, and TNF- $\alpha$ in BV2 microglia cells via suppression of the NF- $\mathrm{kB}$ pathway. Food Chem. Toxicol. 2011, 49, 2758-2764. [CrossRef]

20. Fan, Q.Y.; Yin, X.; Li, Z.H.; Li, Y.; Liu, J.K.; Feng, T.; Zhao, B.H. Mycophenolic acid derivatives from cultures of the mushroom Laetiporus sulphureus. Chin. J. Nat. Med. 2014, 12, 685-688.

21. Saba, E.; Son, Y.; Jeon, B.R.; Kim, S.-E.; Lee, I.-K.; Yun, B.-S.; Rhee, M.H. Acetyl Eburicoic Acid from Laetiporus sulphureus var. miniatus Suppresses Inflammation in Murine Macrophage RAW 264.7 Cells. Mycobiology 2015, 43, 131-136. [CrossRef]

22. Wang, J.; Zhang, P.; He, H.; Se, X.; Sun, W.; Chen, B.; Zhang, L.; Yan, X.; Zou, K. Eburicoic acid from Laetiporus sulphureus (Bull.:Fr.) Murrill attenuates inflammatory responses through inhibiting LPS-induced activation of PI3K/Akt/mTOR/NF- $\mathrm{KB}$ pathways in RAW264.7 cells. Naunyn-Schmiedeberg's Arch. Pharmacol. 2017, 390, 845-856.

23. Petrović, J.; Glamočlija, J.; Stojković, D.S.; Ćirić, A.; Nikolić, M.; Bukvicki, D.; Guerzoni, M.E.; Soković, M.D. Laetiporus sulphureus, edible mushroom from Serbia: Investigation on volatile compounds, in vitro antimicrobial activity and in situ control of Aspergillus flavus in tomato paste. Food Chem. Toxicol. 2013, 59, 297-302. [CrossRef]

24. Lin, W.C.; Lee, M.T.; Lin, L.J.; Chang, S.C.; Lee, T.T. Immunomodulation properties of solid-state fermented Laetiporus sul-phureus ethanol extracts in chicken peripheral blood monocytes in vitro. Braz. J. Poult. Sci. 2019, 21, 1-10. [CrossRef]

25. NRC (National Research Council). Nutrient Requirements of Poultry, 9th Revised ed.; The National Academies Press: Washington, DC, USA, 1994. 
26. AOAC-Association of Official Analytical Chemists. Official Methods of Analysis of the Association of the Analytical Chemists; AOAC: Rockville, VA, USA, 2016.

27. Wheeler, C.R.; Salzman, J.A.; Elsayed, N.M.; Omaye, S.T.; Korte, W., Jr. Automated assays for superoxide dismutase, catalase, glutathione peroxidase, and glutathione reductase activity. Anal. Biochem. 1990, 184, 193-199. [CrossRef]

28. Yagi, K. Simple Assay for the Level of Total Lipid Peroxides in Serum or Plasma. Free Radic. Antioxid. Protoc. 2003, 108, 101-106. [CrossRef]

29. Paglia, D.E.; Valentine, W.N. Studies on the quantitative and qualitative characterization of erythrocyte glutathione perox-idase. J. Lab. Clin. Med. 1967, 70, 158-169.

30. Baker, M.A.; Cerniglia, G.J.; Zaman, A. Microtiter plate assay for the measurement of glutathione and glutathione disulfide in large numbers of biological samples. Anal. Biochem. 1990, 190, 360-365. [CrossRef]

31. Lin, C.C.; Lin, L.J.; Wang, S.D.; Chiang, C.J.; Chao, Y.P.; Lin, J.; Kao, S.T. The effect of serine protease inhibitors on airway inflammation in a chronic allergen-Induced asthma mouse model. Mediat. Inflamm. 2014, 2014, 879326. [CrossRef]

32. McMahon, M.; Thomas, N.; Itoh, K.; Yamamoto, M.; Hayes, J.D. Dimerization of substrate adaptors can facilitate cul-lin-mediated ubiquitylation of proteins by a "tethering" mechanism: A two-site interaction model for the Nrf2-Keap1 complex. J. Biol. Chem. 2006, 281, 24756-24768. [CrossRef]

33. Calabrese, V.; Butterfield, D.A.; Scapagnini, G.; Stella, A.G.; Maines, M.D. Redox Regulation of Heat Shock Protein Expression by Signaling Involving Nitric Oxide and Carbon Monoxide: Relevance to Brain Aging, Neurodegenerative Disorders, and Longevity. Antioxid. Redox Signal. 2006, 8, 444-477. [CrossRef]

34. Arellano-Buendía, A.S.; Tostado-González, M.; García-Arroyo, F.E.; Cristóbal-García, M.; Loredo-Mendoza, M.L.; Tapia, E.; Sánchez-Lozada, L.G.; Osorio-Alonso, H. Anti-Inflammatory Therapy Modulates Nrf2-Keap1 in Kidney from Rats with Diabetes. Oxidative Med. Cell. Longev. 2016, 2016, 1-11. [CrossRef]

35. Lin, W.C.; Lee, M.T.; Chang, Y.L.; Shih, C.H.; Chang, S.C.; Yu, B.; Lee, T.T. Effects of mulberry leaves on production per-formance and the potential modulation of antioxidative status in laying hens. Poult. Sci. 2017, 96, 1191-1203. [CrossRef] [PubMed]

36. Sumida, S.; Tanaka, K.; Kitao, H.; Nakadomo, F. Exercise-induced lipid peroxidation and leakage of enzymes before and after vitamin E supplementation. Int. J. Biochem. 1989, 21, 835-838.

37. Cardona, F.; Lacueva, M.C.A.; Tulipani, S.; Tinahones, F.J.; Queipo-Ortuño, M.I. Benefits of polyphenols on gut microbiota and implications in human health. J. Nutr. Biochem. 2013, 24, 1415-1422. [CrossRef]

38. Turner, J.R. Intestinal mucosal barrier function in health and disease. Nat. Rev. Immunol. 2009, 9, 799-809. [CrossRef]

39. Parlato, M.; Yeretssian, G. NOD-Like Receptors in Intestinal Homeostasis and Epithelial Tissue Repair. Int. J. Mol. Sci. 2014, 15, 9594-9627. [CrossRef]

40. Heazlewood, C.K.; Cook, M.C.; Eri, R.; Price, G.R.; Tauro, S.B.; Taupin, D.; Thornton, D.J.; Png, C.W.; Crockford, T.L.; Cornall, R.J.; et al. Aberrant Mucin Assembly in Mice Causes Endoplasmic Reticulum Stress and Spontaneous Inflammation Resembling Ulcerative Colitis. PLoS Med. 2008, 5, e54. [CrossRef]

41. Zhao, Z.; Qu, W.; Wang, K.; Chen, S.; Zhang, L.; Wu, D.; Chen, Z. Bisphenol A inhibits mucin 2 secretion in intestinal goblet cells through mitochondrial dysfunction and oxidative stress. Biomed. Pharmacother. 2019, 111, 901-908. [CrossRef]

42. Kurutas, E.B. The importance of antioxidants which play the role in cellular response against oxidative/nitrosative stress: Current state. Nutr. J. 2015, 15, 1-22. [CrossRef]

43. Sun, K.; Lei, Y.; Wang, R.; Wu, Z.; Wu, G. Cinnamicaldehyde regulates the expression of tight junction proteins and amino acid transporters in intestinal porcine epithelial cells. J. Anim. Sci. Biotechnol. 2017, 8, 1-8. [CrossRef]

44. Osho, S.; Adeola, O. Chitosan oligosaccharide supplementation alleviates stress stimulated by in-feed dexamethasone in broiler chickens. Poult. Sci. 2020, 99, 2061-2067. [CrossRef] [PubMed]

45. Damiano, S.; Sasso, A.; De Felice, B.; Di Gregorio, I.; La Rosa, G.; Lupoli, G.A.; Belfiore, A.; Mondola, P.; Santillo, M. Quercetin Increases MUC2 and MUC5AC Gene Expression and Secretion in Intestinal Goblet Cell-Like LS174T via PLC/PKC $\alpha /$ ERK1-2 Pathway. Front. Physiol. 2018, 9, 357. [CrossRef]

46. Xu, Z.R.; Hu, C.H.; Xia, M.S.; Zhan, A.X.; Wang, M.Q. Effects of dietary fructooligosaccharide on digestive enzyme activities, intestinal microflora and morphology of male broilers. Poult. Sci. 2003, 82, 1030-1036. [CrossRef] [PubMed]

47. Parsaie, S.; Shariatmadari, F.; Zamiri, M.; Khajeh, K. Influence of wheat-based diets supplemented with xylanase, bile acid and antibiotics on performance, digestive tract measurements and gut morphology of broilers compared with a maize-based diet. Br. Poult. Sci. 2007, 48, 594-600. [CrossRef] [PubMed]

48. Viveros, A.; Chamorro, S.; Pizarro, M.; Arija, I.; Brenes, A. Effects of dietary polyphenol-rich grape productson intestinal microflora and gut morphology in broiler chicks. Poult. Sci. 2011, 90, 566-578. [CrossRef] [PubMed] 